\title{
THE EFFECTIVENESS OF USING HANGMAN GAME TO STRENGTHEN YOUNG LEARNERS' VOCABULARY
}

\author{
Munikasari, Sudarsono, Dwi Riyanti \\ Program Studi Pendidikan Bahasa Inggris FKIP Untan Pontianak \\ Email: sarimunika38@gmail.com
}

\begin{abstract}
This research was conducted to find out the evidence of Hangman game in strengthening young learners' vocabulary to the Year-7 students of SMP Negeri 4 Teluk Keramat-Sambas in Academic Year 2019/2020. This research was a pre-experimental research with one group pre-test and post-test design. The population of this research was all of Year-7 students with the total number of students were 114 students. The cluster random sampling was taken in this research as the technique of sampling, the participants consisted of 26 students. Referring to the research findings, it revealed that the technique could make students' vocabulary increased significantly. It can be seen when the students learn vocabulary. Their attention and involvement indicated that the technique gave positive effect on students' vocabulary mastery. They already understood the meaning and how to spell words correctly through Hangman game. The result of the research showed that Hangman game was effective to increase students' vocabulary achievement. It was proven by the result of t-test computation is higher than t-critical value (9.24>2.060). This means that the Null Hypothesis $\left(H_{0}\right)$ which is the implementation of Hangman game does not affect the young learners' vocabulary significantly was rejected, while the Alternative Hypothesis which is the implementation of Hangman game affect the young learners' vocabulary significantly was accepted. The score of effect size was 1.8 and qualified as strong effect. To conclude, Hangman game enabled the students to recollect vocabulary easily and generate the students' motivation in learning process. Thus, the writer suggested this technique to be implemented in teaching vocabulary.
\end{abstract}

Keywords: Hangman Game, Vocabulary

To cite this paper (in APA style):

Munikasari, Sudarsono, \& Riyanti, D. (2021). The effectiveness of using Hangman game to strengthen young learners' vocabulary. Journal of English Education Program, 2(1), 57-65. http:/ / dx.doi.org/10.26418/jeep.v2i1.43328

\section{INTRODUCTION}

Vocabulary is the fundamental element for language learners. It is the basic resource for any language classes. Vocabulary has the greater role that supports all language skills. The learners will speak, listen, read and write 
well if they have sufficient numbers of vocabularies. Harmer (2001, p.15) stated that having many vocabularies, learners will be able to comprehend reading materials, catch other talking, give responses, speak fluently and write various topics. Students cannot compose a sentence in writing and speaking without vocabulary. Students will find difficulty to understand what they read and listen with poor vocabulary. As a consequence, students should master an adequate number of vocabulary and they must learn the forms and the meanings of words.

Therefor, developing students' vocabulary should be taken into consideration.

From the observation that has been done by writer, the Year-7 students of SMP Negeri 4 Teluk Keramat were indicated to have lack of vocabulary. They have low achievement in vocabulary. They did not have English subject in their elementary school. Therefore, they have to introduce to English vocabulary because this is the first time for them. They also have to maintain the vocabulary that they have learned before. Referring to the problems, the writer must apply an appropriate technique to teach vocabulary.

Based on those, the writer needs to propose the appropriate teaching technique in order to make students interested on learning vocabulary and enjoy the circumtances. Teaching vocabulary by using game is suitable for students of junior high school. A game provide motivation, decrease students' stress, and give them the opportunity to have a real communication. But, using game in classroom should not lose the pedagogical values. There are many kinds of games that can be used to teach vocabulary. In this case, the writer decided to apply Hangman game because this technique provide motivation for students to learn vocabulary.

Hangman is a guessing game which is represented with a set number of dashes. The dashes consisted of unknown words and the clues. It involves the progressive drawing, a line for each incorrect answer. Hangman game played by two or more people that consist a host and players. The players guess letter by letter, while the host draw the part of hangman. This game focus on spelling, pronunciation and vocabulary. Wiratania (2018), Hangman game can be used to enlarge vocabulary mastery, practice spelling, and trained students' concentration. This game helps teacher in controlling classroom. While the students are playing Hangman game in the classroom, the teacher observes the process of acquiring vocabulary.

According to Prasetiawati as cited in Wiratania (2018), there are some advantages of Hangman game. First, Hangman game provide motivation for students. It can make students interested in the language learning. Second, Hangman game can avoid the monotony. Third, the students' skill particularly for pronunciation, concentration and spelling can be improved. 
Fourth, it trains them to be competed naturally and also cooperated at the same time.

Descriptive text is a text which describes and reveal a particular person, place and thing. In descriptive text students would find the language features that match with vocabulary learning. Those such as the use of noun, adjective, and action verb. Besides, in year-7 of Junior High School, the Curriculum 2013 includes descriptive text as the material. It is exists on the basic competency point 3.7 and 4.7. In line with this, the descriptive text was chosen by the researcher to teach vocabulary.

Previous research conducted by Hidayat (2015) in Year-7 of MTs Negeri Sausu. He stated that students' vocabulary increase after implementing Hangman game technique. The writer also found a similar research entitled "Teaching Vocabulary by Using Hangman Game to Eight Grade students SMP DDI SSA Pontianak" conducted by Evi from Tanjungpura University. The result of the study revealed that the use of Hangman game technique to teach vocabulary was effective and it is a helpful technique to Year-8 students of SMP DDI SSA Pontianak. Therefore, the writer is still curious on Hangman game technique for students of SMP Negeri 4 Teluk Keramat.

The researcher conducted a pre experimental research in order to examine Hangman Game on strengthening young learners vocabulary. The study focused on the use of Hangman game to strengthen vocabulary on descriptive text to year - 7 of SMP Negeri 4 Teluk Keramat.

\section{RESEARCH METHOD}

The writer used pre-experimental study with single group pre-test and post-test design. Pre-test was administered to measure the initial achievement students' ability of mastery vocabulary. The purpose is to collect data before applying Hangman game. For the treatment, the researcher used Hangman game to teach students' vocabulary. In the process of teaching vocabulary by using Hangman game, the researcher apply several procedures in using this technique as follows: 1) The researcher explained about the instructions of Hangman game, 2) The researcher divided the class into 6 groups, each group consists of a host and players, 3) The writer displayed a text with a series of dashes, these dashes represent the series of letters that make up the word, 4) The students started playing Hangman game, the players guessed letter by letter, meanwhile every host in group ready to draw the component of hanged man or fill the correct letter in the appropriate dash, 5) If the players guess the correct letter, then the host fill the letter into relevant dash. Meanwhile if they guess the wrong letter, the host draw one component of hangman, 6) The writer gave opportunity to answer the dashes in group, 7) The writer shows the answer of the hangman game. Then post-test was administered to measure students' achievement after applying Hangman game. The pre-experimental design can be represented in Table 1: 
Table 1. One group pre-test and post-test design

\begin{tabular}{ccc}
\hline Pre-test & Treatment & Post-test \\
\hline $\mathrm{X}_{1}$ & $\mathrm{~T}$ & $\mathbf{X}_{2}$ \\
\hline & (Cohen et al 2007, p.212)
\end{tabular}

The population of this research was the Seventh Grade Students of SMP Negeri 4 Teluk Keramat as in Academic Year 2019/2020. It consists 114 students. The cluster random sampling was selected as the technique of sampling in which each individual in the population in the classroom has an equal chances of being selected in the research. The researcher chose the sample randomly by lottery, so the sample of this research is VII A that consists of 26 students.

The writer used measurement technique as the technique of data collection. The tool of data collection in this research is a test, especially multiple choice test. The test were given twice. The first was pre test, it collected to know the score about the students' knowledge in vocabulary before treatment. The second test was post-test, it collected after the treatment. The specification of the items include, 30 items of objective. The researcher constructed the test . It derived from a specification of Vocabulary Test. A good test items according to Brown (2004, p.19) is effective and can be applied if possessed two qualities, i.e. validity and reliability.

\section{Validity}

A valid instrument must have high validity. Ary et al. (2010, p.225) state, "Validity was defined as the extent to which an instrument measured what is claimed to measure." Content validity was applied to assure the test that is relevant with the materials that have learned by students. It measured from the specification of test items. The specification of test items could be seen on the table1.

Table 2 Specification of Vocabulary Test

\begin{tabular}{ccc}
\hline Vocabulary & Number & Total Number \\
\hline Noun & $3,4,9,11,14,15,17,20,21,27,30$ & 11 \\
\hline Verb & $1,5,6,7,8,18,19,22,26,29$ & 10 \\
\hline Adjective & $2,10,12,13,16,23,24,25,28$ & 9 \\
\hline Total Number & & 30 \\
\hline
\end{tabular}

\section{Reliability}

A reliable test is consistent and dependable. The test should be consistent and stable although it applied at different respondent and time. Fraenkel (2008, p.154), stated that, reliability is the capabilty of an instrument to give consistency of score obtained. The reliability was taken from tried out from class VII B. It consists 30 students. The researcher provides formula from Kuder Richardson (KR21). The formula of reliability coeffisien

$$
\mathrm{KR}_{21}=\left(\frac{K}{K-1}\right)\left(\frac{1-M(K-M)}{K(S D)^{2}}\right)
$$




$$
\mathrm{SD}=\sqrt{\frac{\sum x^{2}\left[\frac{\left[x^{2}\right)}{w}\right]}{w}}
$$

Legends :

KR 21 : Coefficient of Kuder Richardson Reliability

$\mathrm{K}$ : the total number of items in the test

$M$ : the mean of test score.

SD : the standard deviation of the test score.

$\sum X^{2}$ : Total Sum of the Squared

$\sum X$ :Total Sum of the Scores

$\mathrm{N}$ : Number of Items

The criteria for the category of reliability coefficient can be seen in Table 3 .

Table 3 Reliability coefficient of the Test Score

\begin{tabular}{cc}
\hline Coeffisien & Reliability of the Test \\
\hline $0.00-0.19$ & Negligible \\
\hline $0.20-0.39$ & Low \\
\hline $0.40-0.59$ & Moderate \\
\hline $0.60-0.79$ & Substantial \\
\hline $0.80-1.00$ & High to Very High \\
\hline
\end{tabular}

(Cohen et al 2007, p.506)

The result of the reliability of test item was 0.43 . Based on the table classification, it classified as "moderate". Therefore, it is reliable for collecting the data.

\section{Level of difficulty}

The level of difficulty analyzed using, (Blerkom, 2009, p.128)

$$
\mathrm{LD}=\frac{H G+L G}{\mathbb{N}}
$$

Legends:

LD : Level of difficulty

HG : The total number of higher group's answer

LG : The total number of lower group's answer

$\mathrm{N}$ : The total number of students

The Level of difficulty classified as following criteria:

Table 3. Level of difficulty

\begin{tabular}{cc}
\hline Difficulty Level Indicator & Qualification \\
\hline Minus- 0.29 & Revised (R) \\
\hline $0.30-0.49$ & Difficult (D) \\
\hline $0.50-0.79$ & Moderate (M) \\
\hline $0.80-100$ & Easy (E) \\
\hline
\end{tabular}

(Blerkom, 2009)

The tried out was taken from VII B learning group to measure the level of difficulty of the test items. It consists of 30 students. It revealed that 2 items are easy, 5 items are moderate, 20 items are difficult, and 3 items have to be revised. The writer has already done the revision for items number 8,13 , and 25 by changing the questions. 


\section{Discriminating Power}

To distinguish between 2 groups, the highest and the lowest scoring group the researcher use discriminating power formula. The formula is provided by the researcher as proposed by Gronlund (1997, p.112):

$$
\mathrm{DP}=\frac{\mathrm{HG}-\mathrm{LG}}{1 / 2 \mathrm{~N}}
$$

Legends :

DP : discriminating power

HG : high group

LG : lower group

$\mathrm{N}$ : number of students

The Item Qualification of Discriminating Power classified as follows.

Table 4 Item Qualification of Discriminating Power

\begin{tabular}{cl}
\hline DP & \multicolumn{1}{c}{ Item Qualification (IQ) } \\
\hline $00-.19$ & Revised (R) \\
\hline $.20-.29$ & Sufficient (S) \\
\hline $.30-.39$ & Good (G) \\
\hline $.40-1.00$ & Very Good (E) \\
\hline \multicolumn{2}{c}{ (Gronlud 1997, p. 113) }
\end{tabular}

The result of the calculation for discriminating power shows that there are 15 items categorized into sufficient, 1 item excellent, 4 items good and 10 items have to be revised.

\section{RESULT AND DISCUSSION \\ Results}

The researcher analyzed the data to answer the research questions and test the hyphothesis. The researcher used t-test and effect size formula to answer the first and second research questions. To compute the data with t-test, the computation of the mean difference (MD) precedes the computation of $t$-test. Meanwhile, the second research question, was computed by the effect size formula.

From the data analysis, the researcher obtained the mean score of pre-test was 41.5, while the mean score of post-test was 59.34. The result showed that the mean score of post-test was higher than the mean score of pre-test. The MD was 17.84. The researcher obtained MD from students' post-test score minus pre-test score.

The calculation of $t$-test indicates 9.24. So, the $t$ ratio is 9.24. Then, the $(\mathrm{df})=$ $\mathrm{N}-1$, it found: $26-1=25$. The $\mathrm{t}$-critical with the significant at 0.05 level and $\mathrm{df}$ 25 is 2.060 . that means t-ratio is higher than $\mathrm{t}$-critical $(9.24>2.060)$. After applying Hangman game, there was improvement from pre-test to post-test. The effect size was 1.8 and categorized as strong effect.

Table 5 Summary of Students' Score Analysis 


\begin{tabular}{ll}
\hline Mean Score of Pre-test & 41.5 \\
\hline Mean Score of Post-test & 59.34 \\
\hline Interval Score & 17.84 \\
\hline Test Significance & 9.2 \\
\hline Effect Size & 1.8 \\
\hline
\end{tabular}

Based on the result of data calculation, it showed that the t-test was higher than $t$ - critical $(9.24>2.060)$. If the obtained $t$ result is bigger to the critical t-value, then "the implementation of Hangman Game affects the young learners' vocabulary significantly" is accepted, meanwhile the null hypothesis $\left(\mathrm{H}_{0}\right)$ is rejected.

\section{Discussion}

Regarding to the data analysis, it was found that the use of Hangman game technique gave the positive contributions toward students' ability to increase vocabulary mastery and also generate the students' motivation in learning process. The majority were enganged in learning vocabulary. They were excited and enthusiastic when acquiring vocabularies. It can be seen when the researcher asked them to guess letter by letter in their group, most of them focus and tried to finish the guessing activity as soon as possible. Supported with a theory by Manan (2016) that Hangman game is a useful technique for students so that they can get a lot of vocabulary and the students can also improve their courage to communicate with their friends, especially in the lesson is proven. The researcher believes that the Hangman game technique provides the students opportunities to practice their vocabulary and bring the good atmosphere into learning activity. In here, they practice on several activities like spelling, pronouncing, guessing letter by letter and also drawing the part of Hangman. Through those activities, students can learn new vocabularies and maintain vocabularies that have learned before. As the result, students' vocabulary had increased significantly.

In this research, the use of Hangman game was highly effective to increase students' vocabulary achievement. It was indicated by the students' mean score of pre-test to post-test, it increased. The effectiveness of the treatment also could be seen by the increasing of number of vocabulary mastery after the treatment applied. Besides, the effect size that obtained was categorized as strong effect. It was consistent with the theory proposed by Novriana (2016) through Hangman game student can enlarge their vocabulary. The findings also extend similar result of previous study done by Hidayat (2015), the result of his research found that after implementing Hangman game technique, the students' vocabulary increase significantly. Similarly, Evi (2017) conducted a study on the use of Hangman game in teaching vocabulary to Year- 8 students. The result revealed that teaching vocabulary by Hangman game was effective and it is helpful technique to the students.

The effectiveness of Hangman game technique on students'vocabulary was also shown by the students' learning process. The students show good participation and attention in learning process. It can be seen when the 
researcher gave first instruction to start the Hangman game. Each group was quite focus to finish the game first. It is supported by Wiratania (2018), Hangman game supports students to be interested in learning English and it also provides motivation for students.

Through Hangman game, the students able to place the words in a sentence orderly, they able to spell English word fluently and also identify the meaning of words. Through Hangman game, the students were able to recollect the vocabularies that had been taught before. From another result of conducting Hangman game technique in their research. The students learning achievement was improved by Hangman game technique, so it proves that Hangman game gave positive outcome to the students' voabulary achievement.

In the first treatment, the researcher found that some students did not follow the activities, they did not understand the procedure of playing Hangman game. Because the students did not paying attention to the writer's explanation. They also made mistakes in mentioning the correct letter and some of them repeated the wrong letter that was mentioned before. Thus, the researcher explained on how to guess the word and explained how many chance to guess the word. Then, they also did not understand to draw the correct part of Hangman. Thus, the researcher gave them more explanations and examples on how to draw part by part of Hangman orderly.

Then, in the second treatment, the researcher reviewed vocabularies in the last meeting. In this treatment, the researcher stressed again on how to play Hangman game. The host and the players have different role, so the researcher explained more about it. Then, the researcher instructed them to practice in the group. They guessed letter by letter. The students were getting familiar with the game. They understand well on playing Hangman game.

Furthermore, in the third treatment, the researcher noticed that most of students involved in playing Hangman game. They worked in group while competing with other groups. Then, the researcher instructed every groups to submit their papers that contain the result after playing Hangman game. Those papers contains list of guessed words and also the part of Hanging man that have been drawn by students. Later, the researcher asked them to mention vocabularies that had been taugt in three days treatments. They still remember the pronunciation, spelling, and meaning of those vocabularies.

The researcher found some problems in applying Hangman game in the classroom. First, the class was noisy because the students were competing with each other. The researcher tried to handle this problem by ordering them to allow the rule quietly. Second, a few of students still confused about the rules of playing Hangman game. To overcome this problem, the researcher tried to explained the rules again. 
Overall, based on the data analysis, the calculation classified the effect size as strong effect which asserted in the rejection of the null hypothesis and conclude that the use of Hangman game to strengthen young learners' vocabulary is highly significant to Year-7 students of SMP Negeri 4 Teluk Keramat in Academic Year 2019/2020.

\section{CONCLUSIONS AND SUGGESTIONS Conclusions}

From the entire data on the previous explanation, the researcher can conclude that the implementation of Hangman game contribute a significant enhancement to strengthen young learners' vocabulary of Year-7 students of SMP Negeri 4 Teluk Keramat in academic year 2019/2020.

\section{Suggestions}

From the conclusion of this research, the researcher gives recommendations dealing with the result accomplished. (1) English teachers are suggested to use Hangman game as a technique in teaching vocabulary. It recommended because Hangman game provide motivation for teaching and learning vocabulary. In implementing Hangman game, the classroom would be noisy. English teacher should be well-prepare in order to covers this problem. Beside that, the teacher should explain the order clearly to avoid students' confusion in playing Hangman game. (2) For the students, It suggested that the students should be more responsible in group. The students also suggested to pay attention to the teacher's explanation, especially when the teacher explains the steps of playing Hangman game. (3) For other researchers who have any intention to explore and complete this technique to different kinds of material suitable with its characteristic and school curriculum. Hangman game also possible to be used in other genre of text, for example report text, recount text, and narrative text.

\section{REFERENCES}

Ary, D., Jacob, L., Sorensen, C., \& Razavieh, A. (2010). Introduction to research in education. Belmon: Nelson Education.

Blerkom, M. (2009). Measurement and statistic for proposal. New York: Routledge.

Brown, H. D. (2004). Language and Assessment Principles and Classroom Practices. New York: Longman.

Evi, A. (2017). Teaching Vocabulary By Using Hangman Game to Eighth Grade Students SMP DDI SSA Pontianak. Pontianak: Unpublished Thesis.

Frankel, J. \&. (2008). How to Design and Evaluate Research in Education. New York: McGraw-Hill Companies, Inc.

Gronlud, N. E. (1997). Measurement and Evaluation in Teaching. New York: Macmillan.

Hadvield, J. (1984). Elementary Communication Game, A Collection of Game and Activities for Elementary Students of English. Hongkong: Nelson. 
Harmer, J.(2008). The Practice of English Language Teaching. Cambridge: Longman.

Hidayat, E. W. (2015). Increasing Vocabulary Mastery of the Seventh Grade Students Through Hangman Game. Unpublished Thesis. Palu: Universitas Tadulako.

Novriana, A. (2016). Improving Vocabulary Mastery Through Hangman Game to Elementary School Students. Surakarta: Universitas Sebelas Maret.

Wiratania. (2018). The Effect of Using Hangman Game to Improve Students Vocabulary Mastery at Eight Grade of SMP 1 Semen in Academic Year 2017/2018 . Simki-Pedagogia , 3. 